\title{
Development of the Dimensions of the Teacher's Workplace Well-Being in Islamic School
}

\author{
Tri Na'imah ${ }^{1 *}$ Heru Kurnianto Tjahjono ${ }^{2}$ Abd. Madjid $^{3}$ \\ ${ }^{I}$ Student of Islamic Education Psychology Doctoral Program, Universitas Muhammadiyah Yogyakarta \\ Lecturer in Universitas Muhammadiyah Purwokerto, Indonesia \\ ${ }^{2}$ Universitas Muhammadiyah Yogyakarta, Indonesia \\ ${ }^{3}$ Universitas Muhammadiyah Yogyakarta, Indonesia \\ *Email: tri.naimah.pascal8@mail.umy.ac.id
}

\begin{abstract}
Workplace well-being is often researched in a variety of organizations using a variety of research instruments. However, the variable of workplace welfare has not been widely studied in Islamic education organizations. Therefore, this study aims to develop workplace well-being dimensions in Islamic Kindergartens with qualitative and quantitative research. The research instrument consisted of 17 items produced from literature reviews, interviews with kindergarten teachers, and focus group discussions with a team of experts and kindergarten teachers. The teacher workplace well-being instrument was tested on 121 teachers of TK Aisyiyah, Banyumas Regency, Indonesia. Exploratory Factor Analysis produces six dimensions: the dimension of dedication, the dimension of appreciation, the dimension of positive emotions, the dimension of cooperation, job satisfaction, and social closeness.
\end{abstract}

Keywords: Dimentions, Workplace well-being, Teacher, Islamic School

\section{INTRODUCTION}

Many experts have developed the concept of wellbeing, but basically, all the well-being ideas come from two philosophical schools, namely hedonic and eudaimonia [1]. During its development, research on well-being is dominated by two main approaches, namely hedonic and eudaimonic [2], [3]. However, this condition becomes interesting because there is no uniformity in explaining the concept of well-being with hedonic and eudaimonic approaches due to differences in the experts' perspective; this shows that the study of well-being is still developing.

The hedonic approach perceives that human life aims to seek pleasure and avoid pain to create temporary well-being [1]. Thus well-being is a pleasant concept that represents subjective well-being and has components such as life satisfaction, positive feelings, and the absence of negative emotions.

The eudaimonic approach argues that well-being is not only related to pleasure but the process of striving for perfection and developing self-actualization. For example, promoting autonomy, maturity, authenticity, personal growth, self-acceptance, and life goals [1], [4]
[2]. Furthermore, eudemonic is considered a term representing psychological well-being that focuses on skill development and self-development.

Research on well-being in the workplace, especially educational organizations, is assessed from various variables, including teacher well-being [5], [6], wellbeing in the workplace [7], workplace well-being [8] [9], work-related well-being [10], Subjective WellBeing [11]. However, these studies do not include Islamic values in their research framework. The research instrument used also did not add the dimensions of well-being from an Islamic perspective.

This study will develop a teacher workplace wellbeing instrument in an Islamic education organization setting. The characteristics of Islamic education organizations are different from those of public education organizations. The purpose of Islamic education is to develop intellectual aspects and prepare a rational generation, meet spiritual needs, and develop a personality based on faith in Allah SWT [12].

Organizational environmental conditions will affect the lives of individuals who are in it. The Islamic work environment will shape employee job satisfaction [13], 
to measure well-being requires special instruments. Therefore this study will develop dimensions for the workplace well-being instrument for teachers in Islamic schools.

\section{METHOD}

This research uses a mixed-method, namely research that involves using two methods, namely quantitative methods and qualitative methods in a single study. Researchers use two approaches to gain a complete understanding of the research problem. The strategy used in this research is sequential exploratory research. The investigation begins with data collection and data analysis with qualitative research. It is continued by using quantitative research [14], so qualitative research results are used as input for quantitative research [9].

To develop a variable's dimensions, one can go through the following stages: literature review, interview, and FGD and produce items, evaluation, and item selection and exploratory factor analysis (EFA) [15]. This study, to develop dimensions of workplace well-being for kindergarten teachers through the following stages:

\subsection{Qualitative Research Procedures}

The approach used is meta-ethnographical and grounded theory approaches. The meta-ethnographical approach is an interpretive study of research or literature results with an iterative (spiral) analysis technique. The preliminary study research results are re-interpreted to produce a new theory using cross-thematic analysis [16] so that the aim is not only to combine several concepts but to discover the essence of the theory/concept from primary research [17].

A grounded theory approach is suitable because it explains phenomena, processes and formulates general concepts about a phenomenon that cannot be explained by existing theories. This study uses a grounded theory approach because the researcher tries to understand process-prone symptoms to change, are goal-oriented, and involve intervening conditions that facilitate the appearance of the traits studied [18].

The research data was collected through interviews and focus group discussions. Interviews were conducted with seven teachers of 'Aisyiyah Kindergarten in Banyumas District. In this research, the question is: "What are the characteristics of a prosperous teacher in the workplace?" The researcher is the main instrument, while the supporting tool is the interview guide.

The focus group discussion involved three kindergarten teachers and three experts in helping researchers understand the concepts and dimensions of workplace well-being for kindergarten teachers. The data analysis technique in this grounded-theory research is a constant comparative analysis technique through 3 stages, namely open coding, axial coding, and selective coding [18].

\subsection{Quantitative Research Procedures}

The research was conducted for item selection with exploratory factor analysis. The sample of this research is 121 teachers of Aisyiyah Kindergarten in Banyumas Regency. The characteristics of the respondents are presented in the following table:

Table 1. Characteristics of EFA respondents

\begin{tabular}{|c|c|c|c|c|}
\hline Number & Criteria & Category & Total & Percentage \\
\hline \multirow[t]{3}{*}{1.} & \multirow[t]{3}{*}{$\begin{array}{l}\text { Last } \\
\text { education }\end{array}$} & $\begin{array}{l}\text { High school } \\
\text { and equivalent }\end{array}$ & 24 & $19,8 \%$ \\
\hline & & Diploma & 1 & $0,8 \%$ \\
\hline & & Bachelor & 96 & $79,4 \%$ \\
\hline \multirow[t]{4}{*}{2.} & \multirow[t]{4}{*}{ Age } & 24-32 years & 25 & $20,6 \%$ \\
\hline & & 33-41 years & 40 & $33,1 \%$ \\
\hline & & $42-50$ years & 36 & $29,8 \%$ \\
\hline & & $51-59$ years & 20 & $16,5 \%$ \\
\hline \multirow[t]{4}{*}{3.} & \multirow{4}{*}{$\begin{array}{l}\text { Period of } \\
\text { work }\end{array}$} & $1-9$ years & 37 & $30,6 \%$ \\
\hline & & $10-18$ years & 53 & $43,8 \%$ \\
\hline & & 19-27 years & 22 & $18,2 \%$ \\
\hline & & $28-36$ years & 9 & $7,4 \%$ \\
\hline
\end{tabular}

Source: Research results, 2020

\section{RESULT AND DISCUSSION}

\subsection{Meta-ethnographical results}

The unit of analysis in this study was an article about workplace well-being obtained from the Digital Library ScienceDirect, ProQuest, Emerald and Taylor \& Francis. The keywords used to find the journal were "Workplace well-being", "teacher well-being", "Employe well-being", "teacher psychological wellbeing" and "kesejahteraan guru." The description of the study results as a sample of this research is presented in the following table:

Table 2. Article Description

\begin{tabular}{|c|c|c|c|}
\hline Number & Author & Variable & Sample \\
\hline 1. & Page [19] & $\begin{array}{l}\text { Workplace } \\
\text { Wellbeing }\end{array}$ & $\begin{array}{l}\text { Government } \\
\text { employees }\end{array}$ \\
\hline 2. & Halquist [20] & $\begin{array}{l}\text { Workplace } \\
\text { Wellbeing }\end{array}$ & Teacher \\
\hline 3. & $\begin{array}{l}\text { Royer \& } \\
\text { Moreau [21] }\end{array}$ & $\begin{array}{l}\text { Psychological } \\
\text { Wellbeing at } \\
\text { Work }\end{array}$ & $\begin{array}{l}\text { Kindergarten } \\
\text { Teacher }\end{array}$ \\
\hline 4. & $\begin{array}{l}\text { Collie, Shapka, } \\
\text { Perry, \& } \\
\text { Martin [22] }\end{array}$ & $\begin{array}{l}\text { Teacher Well- } \\
\text { being }\end{array}$ & Teacher \\
\hline 5. & $\begin{array}{l}\text { Stanculescu } \\
{[23]}\end{array}$ & $\begin{array}{l}\text { Subjective well- } \\
\text { being teachers }\end{array}$ & Teacher \\
\hline 6. & $\begin{array}{l}\text { Maulia, } \\
\text { Rakhmawati, } \\
\text { \& Suharno [24] }\end{array}$ & $\begin{array}{l}\text { Kesejahteraan } \\
\text { Psikologis Guru }\end{array}$ & $\begin{array}{l}\text { Kindergarten } \\
\text { teacher }\end{array}$ \\
\hline 7. & $\begin{array}{l}\text { Wei [11]; } \\
\text { Liang, Peng, }\end{array}$ & $\begin{array}{l}\text { Subjective well- } \\
\text { being teachers }\end{array}$ & $\begin{array}{l}\text { Kindergarten } \\
\text { teacher }\end{array}$ \\
\hline
\end{tabular}




\begin{tabular}{|c|c|c|c|}
\hline & $\begin{array}{l}\text { Zhao, \& Wu } \\
\text { [25] }\end{array}$ & & \\
\hline 8. & Warr [26] & $\begin{array}{l}\text { Well being at } \\
\text { work }\end{array}$ & Employees \\
\hline 9. & $\begin{array}{l}\text { Renshaw, } \\
\text { Long, \& Cook } \\
\text { [27] }\end{array}$ & $\begin{array}{l}\text { Subjective well- } \\
\text { being teachers }\end{array}$ & $\begin{array}{l}\text { Kindergarten } \\
\text { teacher }\end{array}$ \\
\hline 10 . & $\begin{array}{l}\text { Acton \& } \\
\text { Glasgow [28] }\end{array}$ & $\begin{array}{l}\text { Teacher Well- } \\
\text { being }\end{array}$ & Teacher \\
\hline 11. & Jones et al., [9] & $\begin{array}{l}\text { Workplace Well- } \\
\text { being teacher }\end{array}$ & $\begin{array}{l}\text { Kindergarten } \\
\text { teacher }\end{array}$ \\
\hline 12. & $\begin{array}{l}\text { Corrêa, Lopes, } \\
\text { Almeida, \& } \\
\text { Camargo [29] }\end{array}$ & $\begin{array}{l}\text { Workplace Well- } \\
\text { being }\end{array}$ & $\begin{array}{l}\text { Public service } \\
\text { employees }\end{array}$ \\
\hline 13. & $\begin{array}{l}\text { Kumar, Pio, } \\
\text { Brewer, } \\
\text { Frampton, \& } \\
\text { Nicholls [30] }\end{array}$ & $\begin{array}{l}\text { Workplace Well- } \\
\text { being }\end{array}$ & $\begin{array}{l}\text { Employee } \\
\text { health agencies }\end{array}$ \\
\hline
\end{tabular}

Source: Research results, 2020

Based on the literature review, the dimensions of workplace well-being are responsibility at work, meaningful work, work independence, work performance, use of sufficient time, job satisfaction, having a workflow, feeling safe at work, recognition of achievement, satisfaction with wages/salary, positive emotions, work involvement, social relations, work efficiency, self-development, feelings of competence, workload well-being, organizational well-being, student interaction well-being, life satisfaction, happiness at work, feelings of fulfillment, feelings of empowerment, gain support, feeling loved, feeling valued, selfresilience, having a purpose, commitment to work, selfefficacy, and satisfaction of tasks.

\subsection{Grounded Theory Results}

The researcher conducted an open coding process from the data obtained using interviews and focus group discussions related to the psychological constructs of the teacher's workplace well-being. Based on axial coding, the researchers focused on four categories related to teacher workplace well-being, namely:

Table 3. Categorization of Workplace Well-Being Guru Constructs

\begin{tabular}{lll}
\hline \multicolumn{1}{c}{ Categorization } & \multicolumn{1}{c}{ Dimension } \\
\hline Affective Dimension & 1. & Responsibility at work \\
& 2. & The meaning of work \\
3. & Independence \\
4. & Sense of security \\
& 5. & Satisfaction with wages \\
& 6. & Positive emotions \\
& 7. & Be grateful \\
& 8. & Compassion \\
& 9. & Happiness at work \\
& 10. Feelings of being fulfilled \\
\hline Social Dimension & 1. & Leadership support \\
& 2. & A sense of kinship \\
& 3. & Friend support \\
& 4. & Proximity to children \\
& 5. & Collaborative work \\
\hline Organizational & 1. & Achievement of work \\
Dimension & 2. & Effective use of time \\
& 3. & Recognition of performance \\
\hline
\end{tabular}

\begin{tabular}{lll}
\hline & 4. & Work involvement \\
& 5. & Work efficiency \\
& 6. & Treated fair \\
& 7. & Have a workflow \\
\hline Devotion Dimensions & 1. & Dedication \\
& 2. & A sense of belonging \\
& 3. & Work as worship \\
& 4. & Heart calls \\
& 5. & Charity \\
& 6. & Ikhlas \\
\hline
\end{tabular}

Source: Research results, 2020

Furthermore, based on these dimensions, items were compiled to measure workplace well-being.

\subsection{Exploratory Factor Analysis (EFA)}

The subsequent analysis is the EFA factor analysis to suppress the number of variables/items by grouping them based on significant correlations between variables to form a set of variables called factors [31] with the following stages:

\subsubsection{Selection of indicators}

The initial stage of factor analysis is to see the Keiser-Meyers-Oklin (KMO) score of the Measure of Sampling Adequacy, which is used to see how relevant the data is for factor analysis. The second process is to know the value of the Barlett Test of Sphericity, which is used to determine whether there is a significant correlation between indicators. The results of the analysis can be seen in the following table:

Tabel 4. KMO and Bartlett's Test

\begin{tabular}{llr}
\hline \multicolumn{2}{l}{$\begin{array}{l}\text { Kaiser-Meyer-Olkin Measure of Sampling } \\
\text { Adequacy }\end{array}$} &, 697 \\
\hline $\begin{array}{llr}\text { Bartlett's Test of } \\
\text { Sphericity }\end{array}$ & Approx. Chi-Square & 390,544 \\
\cline { 2 - 3 } & df & 136 \\
\cline { 2 - 3 } & Sig. &, 000 \\
\hline
\end{tabular}

Source: Research results, 2020

The KMO and Bartlett's Test table shows the feasibility of a variable for factor analysis. If the KMO value is more significant than 0.50 , then the factor analysis technique can be continued. In this study, it is known that the amount of KMO $=0.697>0.5$ and the value of Bartlett's Test of Sphericity (sig.) $0.000<0.05$, then the factor analysis can be continued because it meets the first requirements[31].

Furthermore, the researcher also conducted a measure of sampling adequacy (MSA) test on each indicator to find out that each indicator had a strong correlation between variables. Anti-Image Matrices is useful for knowing and determining which items are suitable for use in factor analysis. The values of each MSA are: 
Table 5. Anti-Image Correlation Coefficient

\begin{tabular}{cc}
\hline Items & MSA \\
\hline Items1 & 0,572 \\
\hline Items2 & 0,563 \\
\hline Items3 & 0,777 \\
\hline Items4 & 0,759 \\
\hline Items5 & 0,620 \\
\hline Items6 & 0,713 \\
\hline Items7 & 0,683 \\
\hline Items8 & 0,752 \\
\hline Items9 & 0,584 \\
\hline Items10 & 0,710 \\
\hline Items11 & 0,503 \\
\hline Items12 & 0,703 \\
\hline Items13 & 0,742 \\
\hline Items14 & 0,682 \\
\hline Items15 & 0,715 \\
\hline Items16 & 0,750 \\
\hline Items17 & 0,784 \\
\hline
\end{tabular}

Source: Research results, 2020

All Items have an MSA score> 0.50, thus fulfilling the second requirement for factor analysis because the correlation between indicators is strong so that no Items are issued.

\subsubsection{Extraction and Rotation Factors}

Factor extraction to determine the smallest amount that can be used to represent the relationship between items. Factor rotation is a method used to clarify items that fall into a specific factor. Factor extraction was carried out on all indicators as many as 17 Items. Based on table 6 , there are six factors with the cumulative value of the variance for each indicator of $22,210 \%$, $9.016 \%, 8,274 \%, 7,457 \%, 7,104 \%, 6,352 \%$ so that the total variance is $60,413 \%$, this value is quite good because the total variance that can be explained exceeds $50 \%$. More details are presented in table 6 :

Table 6. Total Variance Explained

\begin{tabular}{cccc}
\hline Component & Total & \%Variance & \% Cumulative \\
\hline 1 & 3,776 & 22,210 & 22,210 \\
\hline 2 & 1,533 & 9,016 & 31,226 \\
\hline 3 & 1,407 & 8,274 & 39,500 \\
\hline 4 & 1,268 & 7,457 & 46,957 \\
\hline 5 & 1,208 & 7,104 & 54,060 \\
\hline 6 & 1,080 & 6,352 & 60,413
\end{tabular}

Source: Research results, 2020

Factor grouping can also be seen in the following scree plot:
Picture 1. Scree Plot Factors formed

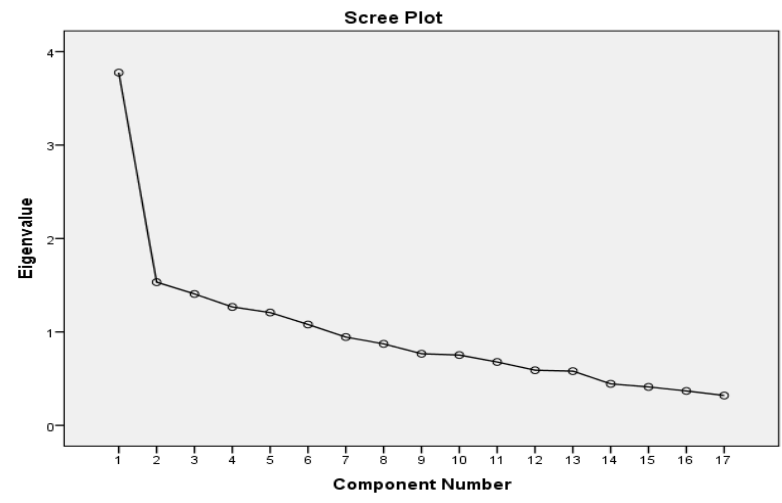

Based on the total variance output explained, six factors are formed because the value of the eigenvalue is greater than 1, and the cumulative variance value is $60,413 \%$. Furthermore, factor rotation is carried out to maximize the grouping of indicators into dimensions. The Varimax factor rotation method used can maximize the amount of variance in the factor load. This technique produces a group of variables with a strong relationship in one factor and has no association with other variables [32]. The factor structure is said to be fit when it has a loading factor greater than 0.3 , so there is no crossloading[33].

\subsubsection{Naming Factors}

The factor naming is given based on the item grouping indicated by the factor load of each item. In this study, the six factors are named: 1) the dimension of dedication, 2) positive emotions, 3) the dimension of appreciation, 4) the dimension of cooperation, 5) the dimension of job satisfaction, 6) the dimension of social closeness. More details can be seen in table 7:

Table 7. Grouping of Factors

\begin{tabular}{|c|c|c|c|}
\hline Factors & Items & Statement & $\begin{array}{l}\text { Loading } \\
\text { Factor }\end{array}$ \\
\hline \multirow{7}{*}{$\begin{array}{l}\text { Factor } \\
1 / \\
\text { Dedication } \\
\text { Dimension }\end{array}$} & Items & Saya bekerja sebagai guru & \multirow[b]{2}{*}{0,554} \\
\hline & 13 & TK karena Lillahi Ta'ala & \\
\hline & Items & Saya merasa pekerjaan & \multirow[b]{2}{*}{0,661} \\
\hline & 14 & $\begin{array}{l}\text { mengajar merupakan } \\
\text { pengabdian kepada Alloh } \\
\text { SWT dan sesama manusia }\end{array}$ & \\
\hline & $\begin{array}{c}\text { Items } \\
15\end{array}$ & $\begin{array}{l}\text { Saya ikhlas menjalankan } \\
\text { tugas sebagai guru di TK }\end{array}$ & 0,611 \\
\hline & $\begin{array}{c}\text { Items } \\
16\end{array}$ & $\begin{array}{l}\text { Saya merasa bekerja } \\
\text { sebagai guru merupakan } \\
\text { amanah }\end{array}$ & 0,717 \\
\hline & $\begin{array}{c}\text { Items } \\
17\end{array}$ & $\begin{array}{l}\text { Saya berkewajiban } \\
\text { menjaga nama baik TK }\end{array}$ & 0,635 \\
\hline \multirow{4}{*}{$\begin{array}{l}\text { Factor } 2 / \\
\text { Positive } \\
\text { emotions }\end{array}$} & Items & Saya mencintai anak didik & \multirow[b]{2}{*}{0,642} \\
\hline & 3 & & \\
\hline & $\begin{array}{c}\text { Items } \\
4\end{array}$ & $\begin{array}{l}\text { Saya memiliki perasaan } \\
\text { welas asih, sehingga } \\
\text { merasa nyaman bekerja } \\
\text { sebagai guru TK }\end{array}$ & 0,682 \\
\hline & $\begin{array}{c}\text { Items } \\
8\end{array}$ & $\begin{array}{l}\text { Saya merasa hidup } \\
\text { menyenangkan karena }\end{array}$ & 0,594 \\
\hline
\end{tabular}




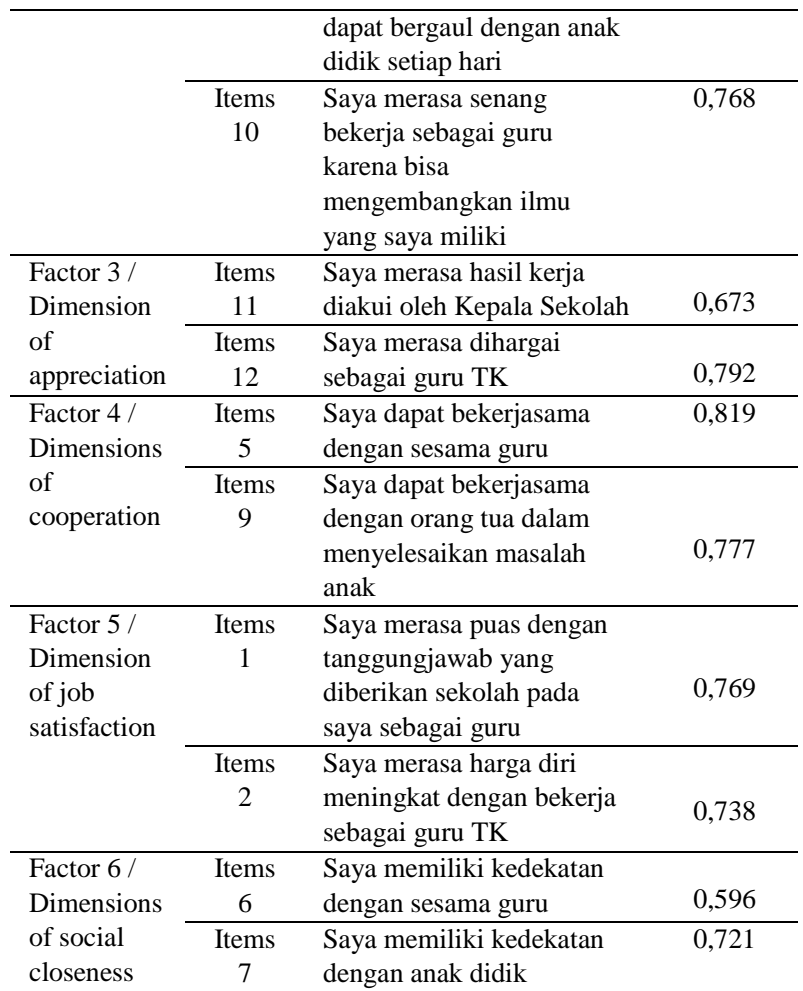

Source: Research results, 2020

These results indicate that workplace well-being is multidimensional. It has six underlying dimensions: the dimensions of dedication, dimensions of positive emotions, dimensions of appreciation, dimensions of cooperation, dimensions of job satisfaction, and social closeness dimensions. These dimensions collectively account for the $60.413 \%$ variance of the teacher's workplace well-being construct. In this study, the development of teachers' workplace well-being dimensions was limited to Islamic school organizations.

The first dimension is "dedication," meaning that teachers feel well-being because they can devote themselves to Islamic institutions/organizations. In Islamic studies, a person tends to surrender in life [34]. In this case, teachers tend to serve the interests of children's education sincerely.

From an Islamic perspective, the goal of education is to guide children to reach the 'truth' in their life [35], integrating four quotients, namely spiritual quotient (SQ), emotional quotient (EQ), adversity quotient (AQ), and intelligence quotient (IQ)[36]. Therefore, students need to be guided by teachers who have high religiosity, reflected in Islamic values [37]. They have high devotion, work sincerely, and work because they feel mandated. Individuals who have high religiosity tend to have flexibility, are more learners, and are adaptive to organizational values [38]. When a person feels that he can serve Allah, he can experience a state of mind that is peaceful, serene, or self-calm (Al-Nafs AlMutmainna) [34], so that he can interpret his work as a form of devotion.
The second dimension is "positive emotions," including feelings of love, compassion, feeling that life is fun, and working happily. Comfort and pleasure in working with students are professional happiness and maintaining welfare at work [28]. Positive emotions are a subjective aspect because only individuals can feel [20]. In Islamic studies, positive emotions are considered necessary but not primary factors in life [39]. Happy feelings are a form of positive emotions. Islam advises happy emotions related to giving or being happy because of achievement [40]. In this study, happy emotions are one of the dimensions to measure teachers' well-being in Islamic educational institutions. Therefore positive emotions are implied in teachers who have the task of providing useful knowledge to students.

Furthermore, the third dimension is "appreciation," namely the feeling of being rewarded for performance as a teacher. Feeling valued and supported at work is part of the welfare at work [28]. The meaning of teachers' well-being is if the teacher is respected, loved, and the emergence of gratitude [8].

The fourth dimension is "cooperation," which is cooperation with fellow teachers and parents. The twoway, reflective horizontal relationship between teachers and school leaders is an essential indicator of teacher well-being [28]. This cohesive relationship is part of social well-being in the workplace [8], [41]

Job satisfaction is the fifth dimension of a teacher's workplace well-being. From an Islamic perspective, job satisfaction is related to sincerity, patience, and gratitude. Working with honesty, patience, and gratitude makes the work process comfortable [42]. An Islamic work environment tends to increase employee job satisfaction because it respects each employee [13].

The 6th dimension is social closeness, which is the teacher's sense of intimacy with fellow teachers and students. The proximity of teachers to students is an essential element in teacher well-being [43]. Social closeness is part of social competence and is the basis for creating a sense of comfort and safety. In a psychometric review, the six dimensions' factor structure is said to be fit because it has a loading factor greater than 0.3 , so there is no cross-loading [33].

This study has limitations because the factors/dimensions of teacher workplace well-being have not been tested using Confirmatory Factor Analysis (CFA). For this reason, future researchers need to conduct a more detailed validity and reliability test. That way, the workplace well-being instrument for teachers in Islamic organizations is ready for research. Researchers also need to replicate the study using research subjects of primary and secondary school teachers. 


\section{CONCLUSION}

The results of this study support the proposition that workplace well-being is multidimensional. Several researchers have developed research instruments on workplace well-being from various perspectives. This study extended the dimensions of teacher workplace well-being in an Islamic school organization setting. The study's findings indicate that the dimensions of teacher workplace well-being in Islamic schools are the dimension of dedication, positive emotional dimensions, dimensions of appreciation, dimensions of cooperation, dimensions of job satisfaction, and dimensions of social closeness.

\section{AUTHORS' CONTRIBUTIONS}

The author makes a substantial contribution to designing research designs, data collection, and data analysis. The author also participates in composing articles and critically revising article content.

\section{ACKNOWLEDGMENTS}

We thank the Universitas Muhammadiyah Purwokerto for providing doctoral study scholarships. We also thank the research team and supervisor at the Islamic Education Psychology Doctoral Program, Universitas Muhammadiyah Yogyakarta

\section{REFERENCES}

[1] E. L. Deci and R. M. Ryan, "Hedonia, eudaimonia, and well-being: an introduction," $J$. Happiness Stud., vol. 9, pp. 1-2, 2008.

[2] V. Huta, "An overview of hedonic and eudaimonic well-being concepts," in Handbook of media use and well-being., no. Nopember, L. Reinecke and M. B. Oliver, Eds. New York: Routledge, 2015.

[3] A. S. Waterman, "Two Conceptions of Happiness : Contrasts of Personal Expressiveness ( Eudaimonia ) and Hedonic Enjoyment," J. Pers. Soc. Psychol., vol. 64, no. 4, pp. 678-691, 1993.

[4] R. M. Ryan and E. L. Deci, "On Happiness and Human Potentials: A Review of Research on Hedonic and," Annu. Rev. Psychol., vol. 52, pp. 141-166, 2001.

[5] S. Turner, N. Zanker, and M. Braine, "An Investigation into Teacher Wellbeing During the Teacher Training Year," Des. Technol. Educ. An Int. J. 17.2, vol. 17, no. 2, pp. 21-34, 2007.

[6] P. A. Jennings, "Early Childhood Teachers , Well-Being , Mindfulness, and SelfCompassion in Relation to Classroom Quality and Attitudes Towards Challenging Students," no. May, pp. 2-13, 2014.

[7] C. Symonds, A. Martins, and H. Hartwell, "Foodscapes and Wellbeing in the Workplace: A University Setting," Nutr. Food Sci., vol. 43, no. 4, pp. 356-364, 2013.

[8] T. Na'imah, R. Kasanah, R. Dwiyanti, and Nur'aeni, "Workplace Spirituality and Emotional Regulation as Determinants Factors of Workplace Well-being Teachers," Jour Adv Res. Dyn. Control Syst., vol. 12, no. 7, pp. 1128-1135, 2020.

[9] C. Jones, F. Hadley, M. Waniganayake, and M. Johnstone, "Find your tribe! Early Childhood Educators Defining and Identifying Key Factors that Support Their Workplace Wellbeing," Australas. J. Early Child., vol. XX, no. X, pp. 1-13, 2019.

[10] Y. Li and R. C. Zhang, "Kindergarten teachers' work stress and work-related well-being: A moderated mediation model," Soc. Behav. Pers., vol. 47, no. 11, pp. 1-12, 2019.

[11] M. H. Wei, "Multiple Abilities and Subjective Well-being of Taiwanese Kindergarten Teachers," Soc. Behav. Pers., vol. 41, no. 1, pp. 7-16, 2013.

[12] R. F. Yasin and M. S. Jani, "Islamic Education: The Philosophy, Aim, and Main Features," Int. J. Educ. Res., vol. 1, no. 10, pp. 1-18, 2013.

[13] M. I. Zainudin, M. S. A. Rashid, Y. Murugeesan, C. Zainal, and S. N. A. Malek, "Islamic Working Environment, Organizational Commitment and Employee's Job Satisfaction and Performance in Malaysia Service Industry: A Conceptual Paper.," Glob. Bus. Manag. Res., vol. 11, no. 1, pp. 436-446, 2019.

[14] J. W. Creswell, Research Design (Qualitative, Quantitative and Mixed Methods Approaches. Los Angeles: Sage Publications, 2014.

[15] M. Anwar and M. Anis-ul-Haque, "Development of School Climate Scale (SCS) : Measuring Primary School Teachers' Perceptions in Islamabad, Pakistan," $F W U J$. Soc. Sci., vol. 8, no. 2, pp. 52-58, 2014.

[16] G. W. Noblit and R. D. Hare, MetaEthnography: Synthesizing Qualitative Studies. London: Sage Publications, 1988.

[17] B. Riyono, Motivasi dengan Perspektif Psikologi Islam. Yogyakarta: Quality Piblishing, 2012.

[18] M. Thi Thanh Thai, L. Choy Chong, and N. M. Agrawal, "The Qualitative Report Straussian Grounded-Theory Method: An Illustration," Qual. Rep., vol. 17, no. 52, pp. 1-55, 2012. 
[19] K. Page, "Subjective wellbeing in the workplace," Deakin University, 2005.

[20] R. A. Halquist, "New teachers and Wellbeing," 2018.

[21] N. Royer and C. Moreau, "A Survey of Canadian Early Childhood Educators' Psychological Wellbeing at Work," Early Child. Educ. J., vol. 44, no. 2, pp. 135-146, 2016.

[22] R. J. Collie, J. D. Shapka, N. E. Perry, and A. J. Martin, "Teacher Well-Being: Exploring Its Components and a Practice- Oriented Scale," J. Psychoeduc. Assess., vol. 33, no. 8, pp. 744756,2015

[23] E. Stanculescu, "Psychological Predictors and Mediators of Subjective Well-being in a Sample of Romanian Teachers," Rev. Cercet. si Interv. Soc., vol. 46, pp. 37-52, 2014.

[24] D. Maulia, E. Rakhmawati, and A. Suharno, "Makna Kesejahteraan pada Guru Pendidikan Anak Usia Dini," J. Psikol. Integr., vol. 6, no. 2, pp. 176-189, 2018.

[25] J. Liang, L. Peng, S. Zhao, and H. Wu, "Relationship among Workplace Spirituality, Meaning in Life, and Psychological Well-being of Teachers," Univers. J. Educ. Res., vol. 5, no. 6, pp. 1008-1013, 2017.

[26] P. Warr, "A conceptual framework for the study of work and mental health," Work Stress, vol. 8, no. 2, pp. 84-97, 1994.

[27] T. L. Renshaw, A. C. J. Long, and C. R. Cook, "Assessing Teachers ' Positive Psychological Functioning at Work: Development and Validation of the Teacher Subjective Wellbeing Questionnaire," Sch. Psychol. Q., vol. 30, no. 2, pp. 289-306, 2015.

[28] R. Acton and P. Glasgow, "Teacher Wellbeing in Neoliberal Contexts: A Review of the Literature," Aust. J. Teach. Educ., vol. 40, no. 8, pp. 99-114, 2015.

[29] J. S. Corrêa, L. F. D. Lopes, D. M. Almeida, and M. E. Camargo, "Workplace Wellbeing and Burnout Syndrome: Opposite faces in Penitentiary Work," Rev. Adm. Mackenzie, vol. 20, no. 3, pp. 1-30, 2019.

[30] R. Kumar, F. Pio, J. Brewer, C. Frampton, and M. Nicholls, "Workplace Wellbeing in an Urban Emergency Department in Aotearoa New Zealand," EMA - Emerg. Med. Australas., vol. 31, no. 4, pp. 1-7, 2019.

[31] J. F. Hair Jr, W. C. Black, B. J. Babin, and R. E. Anderson, Multivariate Data Analysis, vol. 7. New Jersey: Pearson Prentice Hall, 2010.
[32] I. Ghozali, Aplikasi Analisis Multivariate dengan Program IBM SPSS 25, 9th ed. Semarang: Badan Penerbit Universitas Diponegoro, 2018.

[33] A. B. Costello and J. W. Osborne, "Best Practices in Exploratory Factor Analysis: Four Recommendations for Getting the Most from Your Analysis," Pract. Assessment, Res. Eval., vol. 10, no. 7, pp. 1-9, 2005.

[34] M. Joshanloo, "Islamic Coceptions of WellBeing," in The Pursuits of Human Well-Being, International Handbooks of Quality of Life, R. Estes and M. . Sirgy, Eds. Switzerland: Springer International Publishing, 2017, pp. 109-131.

[35] S. J. A. Shah, "Educational leadership: An Islamic perspective," Br. Educ. Res. J., vol. 32, no. 3, pp. 363-385, 2006.

[36] S. S. Dewi, Sutrisno, and A. Madjid, "The Interconnectedness Of Religiosity And Teachers , Efficacy In The Character Education In Indonesian Islamic Integrated School," Eur. J. Soc. Sci., vol. 5, no. 3, pp. 131-146, 2020.

[37] S. Sutarman, H. K. Tjahjono, and T. Hamami, "The Implementation of Holistic Education in Muhammadiyah's Madrasah Indonesia," Din. Ilmu, vol. 17, no. 2, pp. 191-203, 2017.

[38] M. Palupi and H. K. Tjahjono, "A model of religiousity and organizational justice: The impact on commitment and dysfunctional behavior," in Proceedings of the 27th International Business Information Management Association Conference Innovation Management and Education Excellence Vision 2020: From Regional Development Sustainability to Global Economic Growth, IBIMA 2016, 2016, pp. 1781-1790.

[39] M. Joshanloo, "A Comparison of Western and Islamic Conceptions of Happiness," $J$ Happiness Stud., vol. 14, no. December, pp. 1857-1874, 2013.

[40] M. Ulya, "Emosi Positif Manusia Perspektif AlQuran dan Aplikasinya dalam Pendidikan," ElFurqania, vol. 05, no. 02, pp. 151-177, 2019.

[41] T. Na'imah and R. Dwiyanti, "Resources of Teacher Well-Being at the Workplace," in Proceedings of the 33th International Business Information Management Association Conference, 2019.

[42] Muhtadin, Motivasi dan Kepuasan Kerja, Pedekatan Psikologi dan Islam. Jakarta: Mandala Nasional Publishing, 2014.

[43] Milatz Anne, M. Lüftenegger, and Barbara Schober, "Teachers' Relationship Closeness with Students as a Resource for Teacher 
Wellbeing: A Response Surface Analytical Approach," Front. Psychol., vol. 6, no. December, pp. 1-16, 2015. 